\title{
Prospective Study: Study of Asthma Therapy and the Relationship Between Asthma Control Levels and Quality of Life of Asthma Patients
}

\author{
Pinasti Utami ${ }^{1 *}$ Bangunawati Rahajeng ${ }^{2}$ Razmi Wulan Diastuti ${ }^{3}$ M.T Ghozali ${ }^{4}$ Ingenida Hadning ${ }^{5}$ Nurul \\ Maziyyah $^{6}$ Indriastuti Cahyaningsih ${ }^{7}$ Salmah Orbayinah $^{8}$ \\ 1,2,3,4,5,6,7,8 School of Pharmacy, Faculty of Medicine and Health Sciences, Universitas Muhammadiyah Yogyakarta, Indonesia \\ *Corresponding author. Email: pinasti_wicaksana@gmail.com; pinasti.utami@umy.ac.id
}

\begin{abstract}
Asthma treatment generally aims to control asthma recurrence so that patients can lead an everyday life with few or no symptoms. In addition, low levels of asthma control are associated with a decreased meaning of quality of life. Therefore, this research aims to determine the study of asthma therapy in terms of the rationality of drug use and to determine the relationship between the control level of asthma and the quality of life of asthma patients at Rumah Sakit Khusus Paru 'Respira' Yogyakarta (RSKP Respira Yogyakarta), a lung hospital in Yogyakarta. This observational analytic research used a cross-sectional approach with 30 patients as the respondents. Patient data were collected from November 2019 to February 2020 using Asthma Control Test (ACT) questionnaire to measure the level of asthma control and Mini Asthma Quality of Life Questionnaire (MINI AQLQ) to measure asthma patients' quality of life. Analysis of the relationship between the patients' control level of asthma and the patients' quality of life used the Chi-Square test. The results showed the rational use of medicine in asthma outpatients at RSKP Respira Yogyakarta was that 30 patients (100\%) had the right indication, 27 patients (90\%) received the right drug, 28 patients $(93,33 \%)$ were the right patients, 30 patients $(100 \%)$ had the right dose, and no side effects were found $(100 \%)$. Overall, there were $83.33 \%$ of patients who met the requirements for the rationality of drug use. A $p$-value of $<0.05$ on the Chi-Square test indicated that there was a relationship between the level of asthma control and the quality of life of asthma outpatients at RSKP Respira Yogyakarta.
\end{abstract}

Keywords: Asthma, Asthma Control Test (ACT), control level, Mini Asthma, rationality, quality of life, Quality of Life Questionnaire (MINI AQLQ)

\section{BACKGROUND}

Asthma is one of the causes of mortality and chronic morbidity globally, with patients reaching 300 million and a mortality rate of around 250 thousand each year [1]. According to the World Health Organization (2016), around 235 million people suffered from asthma, with a more than $80 \%$ mortality rate in developing countries [3]. Thus, asthma control is needed to reduce high mortality and morbidity rates. The prevalence of asthma in Indonesia has decreased to 2.4\%, and the highest prevalence of asthma is in the Special Region of Yogyakarta, East Kalimantan, and Bali [2].

Asthma treatment generally aims to control asthma recurrence so that patients can lead an everyday life with few or no symptoms/disturbances. Its specific objectives are to prevent chronic and disturbing symptoms, reduce the use of short-acting $\beta 2$ agonists, maintain normal lung function, and prevent a recurrence. According to Anwar's research (2017), the asthma control level based on the score had the highest proportion, which was the patients with uncontrolled asthma. Poor asthma control is associated with a significant reduction in quality of life [4].
The high prevalence of asthma in Yogyakarta becomes the background for this research entitled "The Study of Asthma Therapy and the Relationship between Asthma Control Level and Quality of Life of Patients in RSKP Respira Yogyakarta". This study aims to determine the relationship between the level of asthma control and asthma patients' quality of life as measured by using the Asthma Control Test (ACT) and Mini Asthma Quality of Life Questionnaire (MiniAQLQ).

\section{RESEARCH METHOD}

This study used an observational analytic design with a cross-sectional approach. This research was conducted at RSKP Respira Yogyakarta, a lung hospital in Yogyakarta during November 2019 - February 2020, and received the Faculty of Medicine and Health Sciences' ethical eligibility approval, University Muhammadiyah Yogyakarta with letter number No. 010/EC-KEPK FKIK UMY/X/2019. The subjects of this study were asthma patients of RSKP Respira Yogyakarta. The respondents' criteria for this research were asthma outpatients willing to become respondents (agreed on informed consent). This study excluded patients who had a 
history of diseases with shortness of breath symptoms, such as acute respiratory infections, pneumonia, pulmonary tuberculosis, chronic obstructive pulmonary disease, lung cancer, and heart failure.

Primary data in this study included the ACT and MiniAQLQ questionnaires. Secondary data in this study were medical records that were used to identify drugs that patients received. In addition, a guideline used to reference asthma therapy was: Global Initiative for Asthma (GINA), Pharmaceutical Care Untuk Penyakit Asma (2007), Pedoman Nasional Asma Anak (2016), Drug Information Handbook (2012), and Pharmacotherapy Handbook 7th Edition (2008). The obtained data were analyzed using SPSS (Statistical Product and Service Solutions) program and the Chi-Square statistical test.

\section{RESULTS}

This research began by conducting a preliminary test for the ACT and Mini AQLQ questionnaires' validity and reliability. As a result, all the questions on the ACT and Mini AQLQ questionnaires had a valid status, where the value of Rcount (0.00) > Rtable (0.44). Reliability tests were then carried out on questions that were previously declared valid (all questions). In this study, the Cronbach's Alpha value for the ACT and MINI AQLQ questionnaires was more than 0.6, so both questionnaires were reliable or consistent.

\subsection{Characteristics of Research Subjects}

In this study, the sample that met the inclusion criteria was 30 patients. Data on the characteristics of asthma outpatients of RSKP Respira Yogyakarta are shown in table 1.

Table 1. Characteristics of research subjects

\begin{tabular}{|c|c|c|c|}
\hline \multicolumn{2}{|c|}{ Characteristics } & Quantity & Percentage (\%) \\
\hline \multirow[t]{2}{*}{ Gender } & Male & 11 & 37.00 \\
\hline & Female & 19 & 63.00 \\
\hline \multirow[t]{3}{*}{ Age } & 2-12 Years & 12 & 40.00 \\
\hline & 13-59 Years & 13 & 43.00 \\
\hline & $>60$ Years & 2 & 7.00 \\
\hline \multirow{4}{*}{$\begin{array}{l}\text { Drug } \\
\text { Type }\end{array}$} & Main Asthma & & 67.70 \\
\hline & Drugs & & \\
\hline & $\begin{array}{l}\text { Asthma } \\
\text { Support Drugs }\end{array}$ & & 25.00 \\
\hline & Other Drugs & & 7.30 \\
\hline \multirow{5}{*}{$\begin{array}{l}\text { Drug } \\
\text { Form }\end{array}$} & Inhalation & 30 & 36.14 \\
\hline & Tablet & 28 & 33.73 \\
\hline & Syrup & 14 & 16.87 \\
\hline & Powder & 10 & 12.05 \\
\hline & Capsule & 1 & 1.20 \\
\hline \multirow{6}{*}{$\begin{array}{l}\text { Amount } \\
\text { of Drugs }\end{array}$} & One & 7 & 23.00 \\
\hline & Two & 5 & 17.00 \\
\hline & Three & 4 & 13.00 \\
\hline & Four & 5 & 17.00 \\
\hline & Five & 7 & 23.00 \\
\hline & Six & 2 & 7.00 \\
\hline
\end{tabular}

\subsection{Review of Asthma Drug Use Therapy}

In terms of rationality, the review of asthma therapy applied 5 criteria: right indication, right patient, right drug, right dose, and awareness of side effects. Details can be seen in table 2.

Table 2. Rational use of asthma drug

\begin{tabular}{lcccc}
\hline \multirow{2}{*}{$\begin{array}{c}\text { Asthma Drug } \\
\text { Criteria }\end{array}$} & \multicolumn{2}{c}{ Quantity } & \multicolumn{2}{c}{ Percentage (\%) } \\
\cline { 2 - 5 } & Correct & Incorrect & Correct & Incorrect \\
\hline Right indication & 30 & 0 & 100.00 & 0.00 \\
Right drug & 27 & 3 & 90.00 & 10.00 \\
Right patient & 28 & 2 & 93,33 & 6,66 \\
$\begin{array}{l}\text { Right dose } \\
\begin{array}{l}\text { Awareness of } \\
\text { side effects }\end{array}\end{array}$ & 30 & 0 & 100.00 & 0.00 \\
\hline
\end{tabular}

\subsection{Relationship between Asthma Control Level and Quality of Life}

Asthma patients with a "partially controlled" level were 17 people $(56.67 \%)$, and patients with an "uncontrolled" level were 13 people $(43.33 \%)$. Distribution data for the frequency of asthma control levels can be seen in table 3 .

Tabel 3. Distribution of Asthma Control Level

\begin{tabular}{lcc}
\hline Asthma Control Level & Quantity (n) & $\begin{array}{c}\text { Percentage } \\
(\%)\end{array}$ \\
\hline Uncontrolled & 13 & $43,33 \%$ \\
Partially controlled & 17 & $56,67 \%$ \\
\hline Total & 30 & $100 \%$ \\
\hline
\end{tabular}

Asthma patients with "good quality of life" were 17 people $(56.66 \%)$ and asthma patients with "poor quality of life" were 13 people (43.33\%). Distribution data for the frequency of asthma patients' quality of life can be seen in table 4.

Tabel 4. Distribution of Asthma Patients' Quality of Life

\begin{tabular}{ccc}
\hline $\begin{array}{c}\text { Patients' Quality of } \\
\text { Life }\end{array}$ & Frequency (n) & $\begin{array}{c}\text { Percentage } \\
(\%)\end{array}$ \\
\hline Good quality of life & 17 & $56,66 \%$ \\
Poor quality of life & 13 & $43,33 \%$ \\
\hline Total & 30 & $100 \%$ \\
\hline
\end{tabular}

In terms of the relationship analysis, the Pearson ChiSquare test resulted in a p-value of $\mathbf{0 . 0 0}<\mathbf{0 . 0 5}$. There was a relationship between the level of asthma control and the quality of life of asthma patients at RSKP Respira Yogyakarta. The details are in the following table

Table 5. Chi-Square Results

\begin{tabular}{llll}
\hline Chi-Square Test & Value & df & $\begin{array}{l}\text { Asymp. Sig. (2- } \\
\text { sided) (p) }\end{array}$ \\
\hline Pearson Chi-Square & 22.41 & 1 & 0.00 \\
\hline
\end{tabular}




\section{DISCUSSION}

\subsection{Characteristics of Research Subjects}

\subsubsection{Based on gender}

Based on table 1, there were 11 male patients $(37 \%)$ and 19 female patients (63\%). These results are in line with the Asthma Center for Disease Control and Prevention (CDC) data in 2017; the prevalence of asthma in women was higher than that of men in America [5]. The number of female sufferers was 15,156, while male sufferers were 10,035 [5]. According to Yung (2018), hormonal fluctuations during menstruation, pregnancy, and menopause in women could cause asthma symptoms [6]. According to Lim RH (2008), asthma was more common in women because it was caused by the frequency of hormone levels in women [7]. The highest prevalence of asthma in women is caused by the hormone estrogen, which can increase eosinophil degranulation, causing asthma. High levels of estrogen can trigger mast cell degranulation. Mast cells are cells that trigger hypersensitivity reactions by releasing histamine, PGD2 prostaglandins, LTC4 leukotrienes, and cytokines, which are factors in asthma occurrence.

\subsubsection{Based on the age}

In this research, most asthma patients were adults with the age range of 19-59 years old, with a total of 13 people; followed by 12 people aged 2-12 years old. Research by Atmoko et al. (2011) revealed that asthma in adulthood could be caused by smoking. It was because this age group was the productive working age [8]. According to Fernandez (2011), factors that often occurred were such as hypersensitivity to animals or allergens, allergic rhinitis, family history, occupational risks, and intolerance to NSAID [9].

\subsubsection{Based on the drug type}

Based on Table 1, the percentage of use of the main asthma medication was $67.60 \%$. The drugs used were the combination of beta-2 agonists and corticosteroids, bronchodilators, leukotriene inhibitors, and corticosteroids (shown in table 6). Meanwhile, the percentage of asthma supporting drugs was $25 \%$ with antibiotics, a combination of antihistamines and decongestants, mucolytics, expectorants, and analgesics-antipyretics. In addition, some patients also received additional drugs for comorbidities such as vitamins and NSAIDs as much as $7.3 \%$.

Table 6. Types of Main Medicine for Asthma

\begin{tabular}{|c|c|c|c|c|}
\hline Drug Types & Drugs & Brands & $\mathbf{n}$ & $\%$ \\
\hline \multirow{2}{*}{$\begin{array}{l}\text { Bronchodilator } \\
+ \\
\text { corticosteroid }\end{array}$} & $\begin{array}{l}\text { Formoterol + } \\
\text { Budesonide }\end{array}$ & Symbicort & 10 & \multirow{2}{*}{40} \\
\hline & $\begin{array}{l}\text { Salmoterol + } \\
\text { Fluticasone }\end{array}$ & Seretide & 16 & \\
\hline \multirow[t]{3}{*}{ Bronchodilator } & Salbutamol & $\begin{array}{l}\text { Salbulin, } \\
\text { salbutamol, }\end{array}$ & 11 & \multirow{3}{*}{30} \\
\hline & Procaterol & meptin & 5 & \\
\hline & Teofilin & $\begin{array}{l}\text { Bronsolvan, } \\
\text { retaphyl }\end{array}$ & 3 & \\
\hline
\end{tabular}

\begin{tabular}{|c|l|l|l|l|}
\hline $\begin{array}{l}\text { Inhibitor } \\
\text { leukotriene }\end{array}$ & Montelukast & Rymont & 4 & 6 \\
\hline Corticosteroid & Fluticasone & Avamys & 1 & \\
\cline { 2 - 4 } & Triamcinolone & Trilac & 12 & \multirow{2}{*}{25} \\
\cline { 2 - 4 } & Metilprednisolone & Metilprednisolon & 3 & \\
\hline \multirow{2}{*}{ Total } & & & 65 & 100 \\
\hline
\end{tabular}

\subsubsection{Based on the drug form}

Asthma treatment can be given in 3 ways: inhalation, oral, and parenteral (intravenous, subcutaneous, intramuscular). The dosage forms that were widely used were inhalation (36.14\%), tablet (33.73\%), syrup (16.87\%), powder (12.05\%) and capsule $(1.20 \%)$. Treatment by inhalation provided a better advantage as it was given directly into the airway (inhalation) compared to oral or parenteral administration. The use of inhalation could achieve high concentrations in the airway and minimize side effects. There were some drugs that could only be given by inhalation as the drugs could not be absorbed if it was given orally.

\subsubsection{Based on the amount of drugs}

Based on table 1, the number of drugs used was 1-6 kinds of drugs. $23 \%$ of patients received 1 type of drug, $17 \%$ of patients received 2 types of drugs, $13 \%$ of patients received 3 types of drugs, $17 \%$ of patients received 4 types of drugs, $23 \%$ of patients received 5 types of drugs, and $7 \%$ of patients received 6 types of drugs.

The difference in the number of drugs obtained indicated that the drugs prescribed depended on each individual's needs. It was due to differences in the diagnosis given by doctors based on the patient's history. In addition, the amount of medication also depended on how severe the patient's asthma was.

\subsection{Review of Asthma Drug Use Therapy}

\subsubsection{Based on the right indication}

The right indication is the accuracy of the use of drugs given for proper diagnosis by doctors . Considering the indications' accuracy, all patients received an indication according to their complaints, as shown in Table 2. Asthma diagnosis was determined based on the patient's symptoms and disease history. Asthma outpatients needed control medication, and if needed, they also got relief for exacerbations. Outpatient asthma treatment was routinely administered to patients to maintain a level of asthma control.

\subsubsection{Based on the right drug}

The appropriate drug is the accuracy of using drugs with indicated diseases, whose benefits and safety have been proven or according to treatment guidelines . Inaccurate use of drugs can worsen the patient's condition. Based on table 19, 27 were appropriate drug prescriptions $(90 \%)$ and 3 inappropriate drug prescriptions $(10 \%)$. The right drug was 
based on the guidelines of Global Initiative for Asthma (GINA), Pharmaceutical Care for asthma, and Pedoman Nasional Asma Anak. The inaccuracy of prescribing the right medication can be seen in table 7 .

Table 7. The inaccuracy of prescribing the right medication

\begin{tabular}{|c|l|l|}
\hline Patient & \multicolumn{1}{|c|}{ Drug Name } & \multicolumn{1}{c|}{ Explanation } \\
\hline 21 & $\begin{array}{l}\text { Salbutamol II } \\
\text { Triamcinolone V } \\
\text { Pseudoephedrine + } \\
\text { triprolidine III }\end{array}$ & $\begin{array}{l}\text { Interaction of Salbutamol } \\
\text { and pseudoephedrine }\end{array}$ \\
\hline 27 & $\begin{array}{l}\text { Salbutamol iii } \\
\text { Triamcinolone vii } \\
\text { Pseudoephedrine + } \\
\text { triprolidine iv }\end{array}$ & $\begin{array}{l}\text { Interaction of Salbutamol } \\
\text { and pseudoephedrine }\end{array}$ \\
\hline 30 & $\begin{array}{l}\text { Theophylline } \\
\text { Methylprednisolone } \\
\text { Montelukast }\end{array}$ & $\begin{array}{l}\text { Theophylline interacts with } \\
\text { methylprednisolone } \\
\text { (monitors closely) and } \\
\text { montelukast with } \\
\text { methylprednisolone (minor) }\end{array}$ \\
\hline
\end{tabular}

The inaccuracy of drug use in this study was found in patients 21,27 , and 30 . The inaccuracy of the drug was due to the interaction of several drugs. In patients 21 and 27, there was an interaction between salbutamol and pseudoephedrine. In patient 30, there was also an interaction between methylprednisolone and theophylline and methylprednisolone with montelukast. According to Yuzkat (2016), the use of single theophylline or single methylprednisolone could cause effects on the diaphragm muscle [10]. Theophylline and methylprednisolone would cause synergistic contraction of the diaphragm that came from the effects of each drug. The use of methylprednisolone and montelukast would decrease montelukast's effect by affecting the metabolism of the CYP3A4 enzyme in the liver or intestine. The interaction between the two drugs was minor, indicating that the interaction was not significant.

The use of pseudoephedrine with salbutamol or other beta-adrenergic groups could increase pulse rate and cytosolic and diastolic blood pressure. It was because the effect of pseudoephedrine was a significant increase in systolic blood pressure [11]. The use of this drug combination was quite clinically significant; it should be avoided in combination and used in particular circumstances.

In this research, the patients did not have any symptoms arising from the effects of the combination of the two drugs. The pharmacist's role was critical in drug selection to identify if there were potential interactions and monitor patients' adverse effects with oral and inhalation therapy [12].

\subsubsection{Based on the right patient}

The right patient is the correct use of the drug given to the patient according to the patient's age and the patient's physiological condition such as contraindications to drugs, allergies, pregnant women, and nursing mothers. Table 21 shows that the accuracy based on patient accuracy was 28 $(93.33 \%)$ correct patient prescriptions and 2 prescriptions $(6.66 \%)$ incorrect patients. There were no patients with special conditions such as pregnancy, breastfeeding, and no patients with drug allergies in this study. The patient inaccuracies are shown in table 8.

Table 8. Inaccuracy based on the right patient

\begin{tabular}{|l|l|l|}
\hline Patient & \multicolumn{1}{|c|}{ Drug Name } & \multicolumn{1}{c|}{ Explanation } \\
\hline 2 & Na. Diclofenac & Contraindication \\
\hline 24 & Na. Diclofenac & Contraindication \\
\hline
\end{tabular}

In table 8 , inaccuracies based on patient exactness were found in patients with 2 and 24. Patients received the drug diclofenac sodium, which was contraindicated in asthmatic patients. Drugs that were likely to worsen asthma patients' condition should be considered, such as the NSAID type (diclofenac sodium and paracetamol).

\subsubsection{Based on the right dosage}

The right dosage is the accuracy of drugs given to patients, in which the amount of drug dose, frequency of drug, and administration method of the drug are in accordance with the guidelines. The distribution of asthma medication use based on the right dosage can be seen in table 9 .

Table 9. Drug Use Based on the Right Dosage

\begin{tabular}{|c|c|c|}
\hline Rationalities & Quantity & Percentage (\%) \\
\hline Correct dosage & 30 & 100 \\
\hline Incorrect dosage & 0 & 0 \\
\hline Total & 30 & 100 \\
\hline
\end{tabular}

Drugs given to patients are tailored to the patient's needs and refer to the dosage in the guideline by considering age and body weight. In this study, no asthma dose was found to be excessive (overdose). The asthma drug given had the right dosage, which was all within the range of doses per day and the minimum recommended dose. However, there were some differences in the frequency of using doses, but they were still within the minimum dose range per day. If the drug dose is excessive, it will endanger the patient and will cause toxic effects.

\subsubsection{Based on the precautions against side effects}

The administration of asthma medication at RSKP Respira Yogyakarta allowed patients to get medication continuously. It can result in an increased incidence of side effects experienced by patients. The use of drugs based on awareness of side effects must pay attention to the information about the drug obtained by the patient.

According to research, the use of inhaled corticosteroids could result in suppression of the hypothalamus-pituitaryadrenal action, slowing growth in children, osteoporosis, diabetes, and respiratory infections [13]. The number of inhaler uses in this study should be of particular concern as it allowed side effects due to the use of inhalation. The pharmacist's role is significant in providing counseling about the use of drugs that patients obtain. Pharmacists are obliged 
to provide education about how to use asthma drugs properly, and pharmacists must also provide education about the side effects of drugs used by patients.

In this study, no side effects were found due to drug use at RSKP Respira Yogyakarta. In table 2, 5 patients did not meet the criteria for drug use rationality, which indicated that $96.66 \%$ had met the standard of rational drug use. Irrational use of asthma drugs could lead to drug side effects, waste of medical costs, and not achieving clinical benefits for the treatment and control of asthma. The goal of rational drug use was to ensure that patients received treatment according to their needs, adequate time, and affordable prices. ${ }^{[1]}$.

\subsection{Analysis of Relationship between Asthma Control Level and Quality of Life}

\subsubsection{Asthma Control Level}

In this study, the level of partially controlled asthma control was 17 people (56.67\%), and the level of uncontrolled asthma control was 13 people (43.33\%). This study is in line with the research conducted by Bhaskara et al. (2018), who conducted a study at the Lung Clinic at Abdul Wahab Sjahranie Hospital Samarinda. This research revealed that patients with uncontrolled asthma control levels were $75 \%$, patients with partially controlled asthma control levels were $25 \%$, and none of the patients had a control level of fully controlled asthma [14].

Some patients had a relatively good control level as they routinely consumed drugs and routinely carried out control at the First Health Facility or RSKP Respira Yogyakarta. Patients with uncontrolled control levels were due to various reasons such as gender, Body Mass Index (BMI), smoking, the severity of asthma, level of patient knowledge, and comorbid diseases.

According to Tovt-Korshynska (2001), women had a greater tendency to have uncontrolled asthma than men. It was due to differences in the size of the airway diameter and lung function; men's were greater than women's [15]. Thomson (2004) pointed out that asthma sufferers who smoked could accelerate the decline in lung function, worsen asthma, and reduce treatment response, affecting asthma control level [16]. In addition, cigarette smoke could damage the airways, poison the bronchial epithelium, increase epithelial permeability, involve inflammatory cells, and cause limited airway development. Asthma patients who smoked had more severe symptoms, causing a higher need for reliever medication and lower health status. It could affect the patient's level of asthma control[8].

According to Lavoie et al. (2006), the higher the Body Mass Index (BMI) value was, the lower the level of asthma control would be [17]. Body Mass Index (BMI) and obesity were potential factors associated with the patients' poor control. According to research, Obesity was a risk factor for obstructive sleep apnea in both children and adults. The accumulating evidence of an association between obesity and asthma is an independent risk factor for asthma exacerbations [18]. Research conducted by Atmoko (2011) revealed that one of the factors in the high prevalence of uncontrolled asthma was because the patient suffered from comorbid diseases [8]. According to Boulet (2012), comorbid diseases often found in asthma patients are allergic rhinitis, allergy to aspirin, sinusitis, CPOD, hormonal disorders, etc. [19]. Comorbid asthma will result in increased health care use, decreased quality of life, and poor asthma control.

In this study, there were 3 patients with comorbidities: patients 2, 4, and 24. Patients 2 and 4 had comorbid arthritis, and patient number 2 had comorbid allergic rhinitis. The inflammatory condition of systemic rheumatoid arthritis could increase asthma risk by a variety of immunological mechanisms. In addition, medications used by arthritis patients can increase the risk of asthma [20]. Allergic rhinitis is a risk factor for asthma and a significant cause of uncontrolled asthma control. Rhinitis is an upper respiratory disease, whereas asthma is a lower respiratory disease. The relationship between the two lies in the inflammatory mediator in which the inflammatory mediator can reach the lower airway from the upper airway through the air and blood vessels. Mediators involved are histamine, leukotrienes, and some cytokines that can spread into the systemic circulation [21].

\subsubsection{Asthma Patients' Quality of Life}

This research found 17 asthma patients with good quality of life $(56.66 \%)$ and 13 asthma patients with poor quality of life $(43.33 \%)$. It is similar to research conducted by Fitri et al. (2016), who examined asthma patients in the Lung Polyclinic of RSUDZA Banda Aceh: 18 patients with poor quality of life, 26 patients with moderate quality of life, and 15 patients with good quality of life [22]. On the MINI-AQLQ questionnaire, the question item from the symptom domain that had the lowest mean was question number 4 , questioning whether the patient was disturbed by coughing. Coughing is an episodic symptom of an inflammatory response to the airways that is common in asthma patients. Usually, the initial symptoms of coughing occur at night or early morning. However, if the patient already has severe, life-threatening symptoms, the asthma patient will experience a very severe coughing attack .

In the limitation domain activity, the question item that had the lowest mean was question number 12, "does the patient have limited strenuous activity". Some patients had low scores on Question 12 due to limitations to doing strenuous activities such as running, exercising, and climbing stairs. Asthma could be mild and did not interfere with daily activities, but could be permanent and interfere with light activities and even daily activities, which could reduce the patient's quality of life.

In the emotional function domain, the question with the lowest score was number 9, questioning whether the patient was disappointed as he had asthma. According to this study, some patients felt disappointed with their asthma, as asthma 
was a disease that could not be cured even though the symptoms could be adequately treated. It was pressure for patients to experience relapse and dependence on treatment, which would impact the patient's psychology.

In the environmental stimulation domain, the question with the lowest score was number 2, "does the patient feel disturbed and should avoid environmental dust". According to this study, many patients were bothered by the presence of environmental dust. Dust is an allergen of asthma etiology, which can be a trigger.

According to Vortmann (2008), patients with a large BMI had a higher degree of asthma and asthma symptoms than asthma patients with a normal BMI. Thus, it could affect the quality of life and affect the patient's physical activity [23]. The effect of increasing BMI on the respiratory system could be attributed to a decrease in the pulmonary compliance system, lung volume, and peripheral airway diameter, which would result in airway hyperreactivity, changes in pulmonary blood volume, and impaired perfusion ventilation function [24].

The length of time suffering from asthma also affects the patient's quality of life. The degree of asthma has an influence on the quality of life of asthma patients. The more severe the degree of asthma is, the lower the quality of life score will be, resulting in a worse quality of life [25]. A study by Moy (2001) showed that asthma severity could be defined by lung function, symptoms, and use of reliever drugs [26]. It correlates with the quality of life as measured using the AQLQ questionnaire. Patients with moderate to severe asthma have a poorer quality of life than patients with mild asthma. Nevertheless, patients who have had asthma for a long time will generally adapt to their asthma and consider the disease as a lifestyle; thus, patients will likely feel no disturbance in their daily activities [25].

\subsubsection{Asthma Control Level}

The results of data interpretation from the Chi-Square test showed a p-value of 0.00 . It indicated that there was a relationship between the level of asthma control and the patient's quality of life. Patients with uncontrolled levels had a poor quality of life, and patients with partially controlled levels had a good quality of life. According to Mayasari (2015), asthma sufferers who had uncontrolled asthma had a worse quality of life than asthma sufferers who had controlled asthma [27]. There was a relationship between asthma control and quality of life for people with asthma.

Patients with uncontrolled asthma control levels were more likely to have a good quality of life, namely, 17 patients $(57 \%)$ and 13 patients $(43 \%)$ with uncontrolled asthma control levels had a poor life quality. In this study, there were no patients with a "fully controlled" level because, in one of the ACT question domains regarding the patient's need for reliever medication, the patient still needed reliever medication. Reliever medication must be consumed regularly every day to control the recurrence of the patient. In this case, the asthma control level was directly proportional to the asthma patient's quality of life. Patients with controlled asthma usually experience milder clinical symptoms so that patients have a normal quality of life. If patients experience an exacerbation (recurrence), It will significantly affect the patient's quality of life[25].

Patients with uncontrolled asthma control levels should improve asthma management properly to reduce asthma recurrence and develop an optimal life quality. All asthma patients were expected to routinely consume the drugs given and routinely carry out controls at RSKP Respira or the Puskesmas to strengthen the level of asthma control and quality of life.

\section{CONCLUSION}

Based on the results of the study on the rationality of drug use in outpatient asthma patients at RSKP Respira Yogyakarta, there were $83,33 \%$ of patients who met the rationality requirements for drug use, and there was a relationship between the level of asthma control and the quality of life of outpatient asthma patients at RSKP Respira Yogyakarta with $\mathrm{p}<0.05$.

\section{REFERENCES}

[1] McPhee, Stephen J., Ganong, William F. 2011. Patofisiologi Penyakit: Pengantar Menuju Kedokteran Klinis. Jakarta: EGC.

[2] Riset Kesehatan Dasar (Riskesdas) (2018). Badan Penelitian dan Pengembangan Kesehatan Kementerian RI tahun 2018, Jakarta.

[3] World Health Organization (WHO). 2016. http://www.who.int/ media centre/factsheets.html; Diakses pada 5 Mei 2018.

[4] Anwar, Nur NY, et al.. 2017. Kajian Terapi Asma dan Tingkat Kontrol Asma Berdasarkan Asthma Control Test $(A C T)$. Proceeding of the 6th Mulawarman Pharmaceuticals Conferences 1. ISSN: 2614-477. https://doi.org/10.25026/mpc.v6i1.246

[5] CDC, 2017. Center for Disease Control and Prevention. [Online] Available at: https://www.cdc.gov/asthma/asthmadata.htm

[6] Yung, J. A., Fuseini, H., \& Newcomb, D. C. 2018. Hormones, sex, and asthma. Annals of Allergy, Asthma \& Immunology, 120(5), 488494. doi:10.1016/j.anai.2018.01.016

[7] Lim RH, Lester K. 2008. Sexual tension in the airways: the puzzling duality of estrogen in asthma. USA: American Journal of Respiratori Cell and Molecular Biology; pp. 499-500.

[8] Atmoko W, Khairina H, Faisal P, Bobian ET, Adisworo MW, Yunus F. 2011. Prevalens asma tidak terkontrol dan faktor faktor yang berhubungan dengan tingkat 
kontrol asma di poliklinik asma RS Persahabatan Jakarta. J Respir Indo.;31: 53-60.

[9] Fernández, R. P. et al. 2011. Risk Factors for Asthma Onset Between the Ages of 12 and 40: Results of the FENASMA Study. Arch Bronconeumol. 2011;47(9):433-440.

[10] Yuzkat, Nureddin, Kati, Ismail, et al.. 2016. Effects of Theophylline with Methylprednisolone Combination Therapy on Biomechanics and Histopathology in Diaphragm Muscles of Rats. Crossmark. doi: 10.1007/s10753-016-0397-0.

[11] Salerno FG, et al. 2009. The extracellular matrix of the lung and airway responsiveness in asthma. Monaldi Arch Chest Dis. 2009; 71: 1, 27-30

[12] Ajimura, C. M. et al. 2018. Drug Interactions with Oral Inhaled Medications. Journal of Pharmacy Technology 1-8. doi: 10.1177/8755122518788809.

[13] Kaur, S. and Singh, V. 2018. Asthma and Medicines Long-Term Side-Effects, Monitoring and Dose Titration. The Indian Journal of Pediatrics. Crossmark

[14] Bhaskara, Y, Bakhtiar, R. and Moerad, E. B. 2018. Hubungan Tingkat Kontrol Asma dengan Kualitas Hidup Pasien Asma di Klinik Paru Rsud Abdul Wahab Sjahranie Samarinda. Samarinda: Jurnal Kedokteran Mulawarman.

[15] Tovt-korshynska, M. I. et al. 2001. Gender differences in psychological distress in adults with asthma. Journal of Psychosomatic Research. 51 629- 637.

[16] Thomson, N. C. (2004). Asthma and cigarette smoking. European Respiratory Journal, 24(5), 822833. doi:10.1183/09031936.04.00039004.

[17] Lavoie, K. L. et al. 2006. Higher BMI is associated with worse asthma control and quality of life but not asthma severity. Respiratory Medicine. 100, 648-657.

[18] Beuther, D. A., Weiss, S. T., \& Sutherland, E. R. 2006. Obesity and asthma. American journal of respiratory and critical care medicine, 174(2), 112-119.

[19] Boulet, L. 2012. Asthma-related comorbidities. Expert Rev. Respir. Med. 5(3), 377-393.

[20] Kim, S. Y. et al. 2019. Increased Risk of Asthma in Patients with Rheumatoid Arthriti: A Longitudinal Follow-Up Study Using A National Sample Cohort. Scientific Reports. Springer US. pp. 1-8. doi: 10.1038/s41598-019-43481-3.

[21] Bergeron, C. and Hamid, Q. 2005. Relationship between Asthma and Rhinitis. Allergy, Asthma, and Clinical Immunology. Volume 1, Number 2, Spring 2005.
[22] Fitri, R. et al.. 2015. Kepatuhan Pengobatan Asma dengan Kualitas Hidup pada Pasien Asma Persisten. Jurnal Respi Indo Vol 36( 3).

[23] Vortmann, M., \& Eisner, M. D. 2008. BMI and Health Status Among Adults with Asthma. Obesity Journal 16(1), 146-152. doi:10.1038/oby.2007.7

[24] Amanda G., 2012. Obesitas dan Asma. RS PMC Pekanbaru, Riau, Indonesia. CDK-189. 39(1):3638(2012).

[25] Imelda S, Yunus F. 2007. Hubungan Derajat Asma Dengan Kualitas Hidup Yang Dinilai Dengan Athma Quality of Life Qustionare. Maj Ked Indo. 2007; 57(12): 437- 445

[26] Moy, M. L., Israel, E., Weiss, S. T., Juniper, E. F., Dubé, L., \& Drazen, J. M. 2001. Clinical Predictors of Healthrelated Quality of Life Depend on Asthma Severity. American Journal of Respiratory and Critical Care Medicine, 163(4), 924 929. doi:10.1164/ajrccm.163.4.2008014

[27] Mayasari A, Setyoko, Novitasari A. 2015. Hubungan Antara Kontrol Asma dengan Kualitas Hidup Anggota Klub Asma di Balai Kesehatan Paru Masyarakat Semarang. Jurnal Kedokteran Muhammadiyah; 2(1): 711 